\title{
Gambaran Enzim Transaminase pada Anak Obesitas Vegetarian
}

\author{
I Ketut Adi Wirawan, IGN Sanjaya, PG Karyana, IGL Sidiartha \\ Bagian Ilmu Kesehatan Anak Fakultas Kedokteran Universitas Udayana/RSUP Sanglah, Denpasar
}

Latar belakang. Seperempat anak dengan obesitas disertai dengan peningkatan enzim transaminase, yaitu alanin tranferase (ALT), dan aspartat transferase (AST). Diet vegetarian saat ini mulai banyak diminati, salah satu tujuannya adalah untuk mencegah obesitas, walaupun obesitas besitas dapat terjadi pada anakanak vegetarian dan non-vegetarian.

Tujuan. Mengetahui dan membandingkan rerata kadar enzim transaminase pada anak obesitas dari komunitas vegetarian dengan anak bukan vegetarian.

Metode. Desain penelitian potong lintang dengan subjek anak obesitas diet vegetarian dan non vegetarian. Populasi target dalam penelitian ini adalah seluruh anak obesitas. Populasi terjangkau adalah anak dengan obesitas dengan diet vegetarian dan non-vegetarian di Denpasar pada periode Januari sampai Februari 2010.

Hasil. Di antara 44 subjek penelitian, 22 anak obesitas pada kelompok diet vegetarian, dan 22 anak obesitas non vegetarian. Rentang usia antara usia 4 tahun sampai 14 tahun. Kejadian obesitas lebih banyak pada anak laki-laki dan berpendidikan sekolah dasar. Tidak ada perbedaan rerata IMT, tekanan darah sistolik dan diastolik antara kedua kelompok. Dari gambaran enzim transaminase didapatkan perbedaan bermakna $(\mathrm{p}=0,017)$ pada kadar ALT antara kedua kelompok. Proporsi peningkatan kadar ALT lebih banyak kejadiannya pada anak obesitas non vegetarian (40,9\%), dibandingkan anak obesitas vegetarian (27,3\%), tetapi tidak bermakna secara statistik.

Kesimpulan. Anak obesitas dengan diit vegetarian mempunyai rerata kadar ALT yang lebih rendah daripada anak obesitas non vegetarian. Sari Pediatri 2014;15(5):289-93.

Kata kunci: obesitas, vegetarian, enzim transaminase

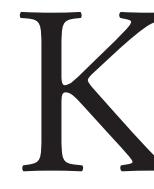

ejadian obesitas meningkat dari tahun ke tahun, baik di negara maju maupun negara berkembang. Organisasi kesehatan dunia (WHO) menyatakan bahwa obesi-

\footnotetext{
Alamat korespondensi:

Dr. I Ketut Adi Wirawan. Bagian/SMF Ilmu Kesehatan Anak FK UNUD/ RSUP Sanglah Denpasar. Jl. Pulau Nias Denpasar Bali. Telepon/Fax: (0361) 244038/(0361) 257387. E-mail: adiwirawan59@yahoo.com
}

tas sudah merupakan suatu epidemi global sehingga merupakan suatu masalah kesehatan yang harus segera ditangani ${ }^{1}$ Data pada tahun 2007, ditunjukkan bahwa kejadian obesitas pada anak dan remaja di Amerika Serikat meningkat tiga kali lipat jika dibandingkan dengan dua dekade terakhir. ${ }^{1}$ Berdasarkan SUSENAS, di Indonesia, kejadian obesitas pada balita mengalami peningkatan baik di perkotaan maupun pedesaan. ${ }^{2}$ 
Obesitas merupakan salah satu faktor predisposisi untuk terjadinya sindrom metabolik. Sindrom metabolik merupakan suatu kriteria yang terdiri dari obesitas, dislipidemia, hiperglikemia, dan hipertensi. Obesitas pada masa anak berisiko tinggi menjadi obesitas di masa dewasa dan berpotensi mengalami penyakit metabolik dan penyakit degeneratif di kemudian hari. ${ }^{3}$

Dapat terjadi resistensi insulin dan stres oksidatif yang memiliki peran penting dalam patogenesis penyakit perlemakan hati non-alkohol pada anak obesitas. Penelitian adanya keterlibatan hati yang asimtomatis pada anak obesitas mendapatkan tingginya kejadian dari steatosis hepatis. Deteksi dini adanya perubahan fungsi hati adalah penting pada anak obesitas. ${ }^{4}$ Kejadian penyakit perlemakan hati non-alkoholik/non-alcoholic fatty liver disease (NAFLD) akan meningkat dengan peningkatan kejadian obesitas. Definisi NAFLD sebagai perubahan fungsi hati dan terjadinya kerusakan sel hati yang menyerupai apa yang terjadi pada perlemakan hati oleh karena alkohol. ${ }^{5}$

Seperempat anak dengan obesitas disertai dengan peningkatan enzim transaminase, yaitu alanine aminotranferase (ALT) dan aspartate aminotransferase (AST). Peningkatan ALT lebih mencerminkan penyakit NAFLD dibandingkan penyakit hati kronis. Peningkatan ALT mengindikasikan adanya resistensi insulin sehingga juga dipakai sebagai petanda diagnostik sindrom metabolik. ${ }^{6}$

Diet vegetarian saat ini mulai banyak dilaksanakan, salah satu tujuannya adalah untuk mencegah obesitas karena beberapa penelitian menyatakan anak vegetarian dan orang dewasa cenderung lebih ramping dibanding rekan mereka non-vegetarian. Bahkan, tahun 2009, American Dietetic Association (ADA) menyimpulkan diet vegetarian yang sehat, gizi yang memadai, dan dapat mencegah serta mengobati kondisi tertentu, seperti penyakit jantung, kegemukan, hipertensi, diabetes tipe II, dan kanker. Obesitas terjadi jika terlalu banyak kalori yang dikonsumsi daripada kalori yang dibutuhkan, yang dapat terjadi pada anak vegetarian atau nonvegetarian.. ${ }^{7}$

Berdasarkan latar belakang tersebut, penelitian ini bertujuan untuk mengetahui rerata kadar enzim transaminase pada anak obesitas dari komunitas vegetarian dibandingkan dengan anak obesitas yang bukan vegetarian.

\section{Metode}

Desain penelitian potong lintang (cross sectional), dengan subjek anak obesitas dengan diet vegetarian dan non vegetarian. Penelitian dilaksanakan di kota Denpasar, Bali, pada periode Januari sampai Februari 2010. Populasi target adalah seluruh anak obesitas. Populasi terjangkau adalah anak obesitas dengan diet vegetarian dan non-vegetarian di Denpasar. Kriteria inklusi adalah anak obesitas usia 2-18 tahun. Kriteria eksklusi adalah mempunyai riwayat penyakit hepatitis virus, memiliki penyakit metabolik (seperti DM tipe II dan hipotiroid) yang diketahui dari anamnesis pada keluarga, sedang dalam pengobatan kemoterapi, aktivitas fisik berupa olahraga yang dilakukan selama lebih dari 90 menit sebanyak lebih dari 3 kali dalam satu minggu sebelum penelitian berlangsung, mengonsumsi alkohol $100 \mathrm{ml}$ lebih dari 1 kali per hari sebelum penelitian berlangsung, merokok lebih dari 20 pak per tahun sebelum penelitian berlangsung, dan dengan tekanan darah tinggi lebih dari persentil ke-95 berdasarkan umur dan jenis kelaminnya.

Besar sampel ditetapkan menggunakan rumus sampel beda 2 proporsi dengan nilai $\alpha 0,05(Z \alpha=$ $1,960)$ dan nilai $\beta 0,2(Z \beta=0,842)$ perbedaan simpang baku $(\mathrm{SB})$ gabungan $(\mathrm{S})$ rerata enzim transaminase pada kelompok anak obesitas dengan diet vegetarian dan non-vegetarian berdasarkan kepustakaan adalah 27 , dan perbedaan rerata $\left(\chi_{1}-\chi_{2}\right)$ enzim transaminase antara kelompok anak obesitas vegetarian dan nonvegetarian yang dianggap bermakna sebesar 20. Besar sampel minimal yang diperlukan 21 anak obesitas dengan diet vegetarian dan 21 anak obesitas dengan diet non-vegetarian.

Kadar enzim transaminase adalah kadar ensim transaminase hati yang meliputi kadar ALT dan AST dengan satuan $\mathrm{mg} / \mathrm{dL}$. Peningkatan ALT pada anak apabila kadarnya lebih dari $30 \mathrm{mg} / \mathrm{dL}$ pada anak laki, atau lebih dari $19 \mathrm{mg} / \mathrm{dL}$ pada anak perempuan. Diet vegetarian adalah jika seorang anak mengkonsumsi semua bahan makanan nabati dan atau susu beserta olahannya setidaknya selama 3 minggu berturut-turut dan didapatkan dari anamnesis. Diet non-vegetarian adalah jika seorang anak mengkonsumsi semua bahan makanan nabati dan hewani secara bersama-sama dan atau terpisah, dan didapatkan dari anamnesis. Definisi operasional obesitas, jika didapatkan penghitungan indeks massa tubuh (IMT) dengan tabel IMT $\geq$ persentil 
ke-95 berdasarkan kurva dari CDC 2000. Tekanan darah tinggi adalah jika seorang anak memiliki tekanan darah lebih dari persentil ke-95 berdasarkan umur dan jenis kelaminnya berdasarkan pemeriksaan tekanan darah dengan posisi berbaring pada lengan kanan setelah penderita beristirahat dari kegiatannya selama lebih kurang 20 menit. Umur ditentukan berdasarkan umur kronologis (tanggal lahir) yang dinyatakan dalam tahun dan didapat dari orangtua atau wali. Pendidikan anak berdasarkan pendidikan formal anak tersebut saat ini, dibagi dalam 3 kelompok yaitu pendidikan pra sekolah, sekolah dasar (SD) dan sekolah menengah pertama (SMP).

\section{Hasil}

Empatpuluh empat subyek penelitian tidak ada yang drop out. Rentang usia subyek penelitian baik vegetarian maupun non-vegetarian (omnivora) terendah berusia 4 tahun dan tertinggi berusia 14 tahun. Kejadian obesitas lebih banyak pada anak laki-laki baik pada kelompok vegetarian maupun non vegetarian. Berdasarkan distribusi pendidikan sebagian besar ada di tingkat sekolah dasar. Tidak terdapat perbedaan rerata IMT, tekanan darah sistolik, dan diastolik antara kelompok vegetarian dan non vegetarian (Tabel 2).

Hasil uji normalitas Kolmogorov-Smirnov Z terhadap parameter transaminase menunjukkan kadar AST $(\mathrm{p}=0,987)$ berdistribusi normal, sedangkan ALT $(p=0,008)$ mempunyai distribusi tidak normal. Terhadap data yang normal maka dilakukan uji t independen sedangkan untuk data yang tidak normal dilakukan uji Mann-Whitney. Perbedaan antara diet vegetarian dan non-vegetarian dengan transaminase tertera pada Tabel 3. Terdapat perbedaan bermakna $(\mathrm{p}=0,017)$ pada kadar ALT antara kedua kelompok, tetapi tidak menunjukkan perbedaan bermakna pada $\operatorname{kadar} \operatorname{AST}(\mathrm{p}=0,807)$.

Tabel 1. Karakteristik demografis sampel

\begin{tabular}{lcccc}
\hline Karakteristik & \multicolumn{2}{c}{ Vegetarian } & \multicolumn{2}{c}{ Non vegetarian } \\
\cline { 2 - 5 } & $\mathrm{n}=22$ & $\%$ & $\mathrm{n}=22$ & $\%$ \\
\hline Jenis kelamin & & & 13 & 59,1 \\
Laki-laki & 12 & 54,5 & 9 & 40,9 \\
Perempuan & 10 & 45,5 & & \\
Pendidikan & & & - & - \\
Prasekolah & 3 & 13,6 & 20 & 90,9 \\
SD & 10 & 45,5 & 2 & 9,1 \\
SMP & 9 & 40,9 & & \\
\hline
\end{tabular}

Tabel 2. Karakteristik indeks masa tubuh dan tekanan darah sampel

\begin{tabular}{lccc}
\hline Karakteristik & Vegetarian & Non vegetarian & $\mathrm{p}$ \\
\cline { 2 - 3 } & Rerata $(\mathrm{SB})$ & Rerata $(\mathrm{SB})$ & \\
\hline Umur & $9,73(3,55)$ & $9,82(1,87)$ & 0,11 \\
IMT & $24,56(5,05)$ & $25,03(5,86)$ & 0,38 \\
Sistolik & $106,82(9,70)$ & $104,32(7,60)$ & 0,86 \\
Diastolik & $68,86(8,00)$ & $65,45(4,86)$ & 0,62 \\
\hline
\end{tabular}

Tabel 3. Perbandingan rerata kadar transaminase anak obesitas vegetarian dan non-vegetarian

\begin{tabular}{lccc}
\hline Parameter & $\begin{array}{c}\text { Vegetarian } \\
(\mathrm{n}=22)\end{array}$ & $\begin{array}{c}\text { Non Vegetarian } \\
(\mathrm{n}=22)\end{array}$ & $\mathrm{p}$ \\
\hline AST $(\mathrm{mg} / \mathrm{dL})$, rerata $(\mathrm{SB})$ & $31,5(15,2)$ & $30,5(12,8)$ & 0,807 \\
ALT $(\mathrm{mg} / \mathrm{dL})$, median (interquartil) & $15(10,75-3375)$ & $21(18,00-37,75)$ & $0,017^{*}$ \\
\hline
\end{tabular}

*uji Mann-Whitney 
I Ketut Adi Wirawan dkk: Gambaran enzim transaminase pada anak obesitas vegetarian

Tabel 4. Proporsi peningkatan ALT pada obesitas vegetarian dan non vegetarian

\begin{tabular}{lcclrc}
\hline Variabel & \multicolumn{2}{l}{ ALT meningkat N (\%) } & \multicolumn{2}{l}{ ALT normal N (\%) } & Total \\
\hline Obesitas veg & 6 & 27.3 & 16 & 72.7 & 22 \\
Obesitas non veg & 9 & 40.9 & 13 & 59.1 & 22 \\
\hline
\end{tabular}

$\mathrm{X}^{2}=0.910 \quad p: 0.340$

Peningkatan kadar ALT lebih banyak pada anak obesitas non vegetarian (40,9\%), dibandingkan anak obesitas vegetarian (27,3\%). Dari hasil uji chi square didapatkan hasil peningkatan ALT yang tidak bermakna $(\mathrm{p}>0,05)$.

\section{Pembahasan}

Beberapa penelitian menunjukkan bahwa prevalensi anak obesitas lebih banyak kejadiannya pada anak lakilaki dibandingkan anak perempuan. Penelitian lain di Seventhday Adventist college ditunjukkan prevalensi yang lebih besar (34\% pada laki-laki dan 28,3\% pada perempuan). Hasil tersebut sejalan dengan data dari National Health and Nutrition Examination Survey (NHANES) tahun 2003-2006 yang menunjukkan persentase terbanyak kejadian risk of overweightlobesitas pada jenis kelamin laki-laki. ${ }^{9}$ Ramadani ${ }^{10}$ melakukan penelitian terhadap 34 anak di komunitas anak vegetarian di Medan, 24 (70,6\%) di antaranya dengan status gizi obesitas, sebagian besar $(61,8 \%)$ anak laki laki, tingkat pendidikan anak sekolah dasar $(58,8 \%)$. Obesitas pada anak sekitar 26,5\% akan tetap obesitas untuk dua dekade berikutnya dan $80 \%$ remaja yang obesitas akan menjadi dewasa yang obesitas. Obesitas pada anak usia 2 sampai 7 tahun apabila disertai adanya komplikasi sindrom metabolik harus diupayakan penurunan berat badan. Obesitas pada anak usia di atas 7 tahun, disertai atau tidak komplikasi sindrom metabolik harus diupayakan menurunkan berat badan. Target penurunan berat badan $2,5-5 \mathrm{~kg}$ atau dengan kecepatan 0,5 - $2 \mathrm{~kg}$ per bulan. ${ }^{11}$

Penelitian kami juga menunjukkan lebih besar subyek penelitian berjenis kelamin laki-laki dan sebagian besar anak sekolah dasar. Untuk mengurangi risiko obesitas pada tahun-tahun berikutnya atau mengurangi komplikasi perlu upaya pengaturan diet kembali.

Pola makan vegetarian yang mencakup makan diet tinggi karbohidrat, rendah lemak, dan berolahraga untuk menjaga otot dapat membantu untuk mencegah atau mengontrol obesitas. Kandungan serat yang tinggi dari diet vegetarian, adanya massa di lambung menimbulkan efek mengenyangkan terutama pada anak obesitas. Serat yang tinggi juga mengurangi asupan energi ataupun penyerapan lemak dan kolesterol. ${ }^{12}$

Penelitian dengan mengambil sampel pada populasi Barbadian Seventh-Day Adventists (SDAs) di Miami suatu studi yang ingin mengetahui hubungan status vegetarian dengan IMT, obesitas, diabetes dan hipertensi, mendapatkan bahwa dengan diet vegetarian kurang dari 5 tahun tidak didapatkan perbedaan kejadian obesitas, dengan komplikasinya diabetes, dan hipertensi jika dibandingkan dengan diet non vegetarian. Namun, apabila diet vegetarian dilakukan rutin dalam waktu lebih dari 5 tahun, nilai IMT pada kelompok vegetarian akan lebih rendah, demikian pula komplikasi hipertensi dan diabetes kejadiannya akan lebih rendah. ${ }^{9}$ Purwana ${ }^{13}$ melakukan penelitian pada kelompok obesitas vegetarian di Denpasar mendapatkan bahwa rerata kadar kolesterol dan trigliserida lebih rendah pada kelompok obesitas vegetarian dibandingkan dengan kelompok obesitas non vegetarian.

Pada penelitian kami antara kelompok vegetarian dengan non vegetarian tidak didapatkan perbedaan variabel IMT dan tekanan darah, jadi hal ini bisa disebabkan karena mulai dietnya kurang dari 5 tahun.

Terdapat dua hipotesis patogenesis terjadinya perlemakan hati pada obesitas. Hipotesis pertama adalah akumulasi lemak pada hati menyebabkan cedera pada sel hati (hepatocyte injury), inflamasi, dan fibrosis. Hipotesis kedua adalah kerusakan hepatoselular karena adanya proses peroksidase lipid yang dipicu oleh stres oksidatif dan kerusakan yang dimediasi oleh sitokin pro-inflamasi. Obesitas dihubungkan dengan peningkatan kadar ALT serum, dan pada anak peningkatan ALT mencerminkan perlemakan hati non alkohol. ${ }^{12}$ Beberapa penelitian menyatakan ALT, petanda primer kerusakan hati atau kecurigaan adanya perlemakan hati, juga sebagai petanda adanya sindrom metabolik pada obesitas. ${ }^{13}$ Dibandingkan dengan kadar AST, ALT lebih spesifik menunjukkan adanya penyakit hati. ${ }^{8}$ 
Kami mendapatkan adanya perbedaan pada rerata kadar ALT antara kelompok obesitas diet vegetarian dengan non vegetarian. Peningkatan kadar ALT lebih banyak didapatkan pada kelompok obesitas non vegetarian $(40,9 \%)$ dibandingkan dengan kelompok diet vegetarian $(27,3 \%)$. Kelemahan penelitian kami adalah penelitian potong lintang deskriptif sehingga tidak dapat mengetahui adanya hubungan sebab akibat. Penelitian ini tidak membedakan durasi anak memulai diet vegetarian.

\section{Kesimpulan}

Didapatkan perbedaan kadar ALT di antara anak obesitas kelompok diet vegetarian dibandingkan dengan diet non-vegetarian. Diet vegetarian mempunyai kadar rerata ALT yang lebih baik dibandingkan dengan diet non-vegetarian.

\section{Daftar pustaka}

1. Gouthamrao MD. Childhood Obesity: Highlights of AMA expert committee recommendations Children's Hospital of Pittsburgh, Pittsburgh, Pennsylvania. Am Fam Physician 2008:53-63.

2. Sjarif DR. Obesitas pada anak dan permasalahannya. Dalam: Trihono P, Purnawati, Sjarif DR, penyunting. Hot Topics in pediatrics II. Naskah lengkap Pendidikan Kedokteran Berkelanjutan XLV FKUI. Jakarta: Balai Penerbit FKUI; 2002.h.219-32.

3. Weiss R, Dziura J, Burgert TS, Tamborlen WV, Taksali SE, Yeckel CW. Obesity and the metabolic syndrome in children and adolescents. NEJM 2005; 350:2361-74.

4. Angulo P. Nonalcholic fatty lever.NEJM 2002;346: 1221-31.

5. Reinehr T, Schmidt C, Gideon de Sousa, Andler W. Association between leptin and transaminases: 1-year follow-up study in 180 overweight children. Metab Clin Experiment 2008;58:497-503.

6. Vajro P, Franzese A, Valerio G, Iannucci MP, Nunzia A. Lackof E. Ursodioxycholic acid for the tretment of liver abnormalities in obesitas children. J Pediatr 2000; 136:739-43.

7. Penney DS, Miller KG. Nutritional counseling for vegetarians during pregnancy and lactation. JMWH 2007;7:37-44.

8. Batres LA, Maller ES. Laboratory assesment of liver function and injury in children. Dalam: Suchy FJ, Sokol RJ, Balistreri WF. editors. Liver disease in children. Edisi kedua. Philadelphia: Lippincott Williams \& Wilkins; 2001.h.155-69.

9. Brathwaite N, Fraser HS, Modeste N, Broome H, King R. Obesity, diabetes, hypertension, and vegetarian status among seventh-day Adventists in Barbados: preliminary results Ethnicity \& Disease. Winter 2003; 13:33-9.

10. Ramadani. Pola konsumsi, status gizi dan prestasi belajar pada anak vegetarian di kota Medan tahun 2004 (Skripsi). Medan: FKM USU, 2004.

11. Sjarif DS. Obesitas Anak dan remaja. Dalam: Sjarif DR, Lestari ED, Mexitalia M, Nasar SD. Penyunting. Buku ajar nutrisi pediatrik dan penyakit metabolik. Edisi pertama. Jakarta: Badan Penerbit IDAI; 2011.h.230-44.

12. Dwyer JT. Health aspects of vegetarian diets. Am J Clin Nutr 1988;48:712-38.

13. Purwana A. Profil lemak anak risk of overweight/obesitas vegetarian dan non-vegetarian di Denpasar. Yogjakarta: Program Pasca Sarjana UGM, 2010.

14. Abe Y, Kikuchi T, Nagasaki K. Usefulness of GPT for diagnosis of metabolic Syndrome in obesitas Japanese children. J Atherosclerosis and Thrombosis 2009;16:9029.

15. Tania SB, Sara ET, Dziura J, Goodman TR, Yeckel CW, Papademetris X. Alanine aminotransferase levels and fatty liver in childhood obesity: associations with insulin resistance, adiponectin, and visceral fat. J Clin Endocrinol. Metab 2006;91:4287-94. 